\title{
CS Research Square \\ Exposure to Air Pollution and Renal Function - An Underestimated Threat?
}

\section{Łukasz Kuźma ( $\nabla$ kuzma.lukasz@gmail.com )}

Department of Invasive Cardiology, Medical University of Bialystok, ul. M. Skłodowskiej-Curie 24 A, 15276 Białystok

\section{Jolanta Małyszko}

Medical University of Warsaw

Hanna Bachórzewska- Gajewska

Medical University of Białystok

Sławomir Dobrzycki

Medical University of Białystok

\section{Research Article}

Keywords: air pollution, particles matter, glomerular filtration rate, chronic kidney disease, sulfur dioxide

Posted Date: January 27th, 2021

DOl: https://doi.org/10.21203/rs.3.rs-146680/v1

License: (1) (1) This work is licensed under a Creative Commons Attribution 4.0 International License. Read Full License 


\section{Abstract}

Introduction: Air pollution contributes to the premature death of approximately 428,000 citizens of Europe every year. The adverse effects of air pollution can be observed not only in respiratory, circulatory, and nervous systems but also in renal function.

Aim: Our goal was to investigate the hypothesis indicating that we can observe the long-term and also short-term impact of air pollution on kidney function.

Methods: We reviewed medical notes of patients hospitalized at Medical University of Bialystok, Poland between 2007-2016. We used linear, log-linear, and logistic regression models to assess the association between renal function and $\mathrm{NO}_{2}, \mathrm{SO}_{2}$, and PMs. Results are reported as beta $(\beta)$ coefficients and odds ratios (OR) for an increase in interquartile range (IQR) concentration with $95 \%$ confidence intervals $(95 \% \mathrm{Cl})$.

Results: 3,554 patients were included into the final analysis. The median age was 66 (IQR 15) and men were in the majority $(53.2 \%, \mathrm{~N}=1891)$. Chronic kidney disease (CKD) was diagnosed in $21.5 \%(\mathrm{~N}=764)$. The long-term increase in annual average concertation of $\mathrm{PM}_{2.5}$ (OR for IQR increase $=1.07 ; 95 \% \mathrm{Cl} 1.01-$ $1.15, \mathrm{P}=0.037$ ) and $\mathrm{NO}_{2}$ (OR for IQR increase $=1.05 ; 95 \% \mathrm{Cl} 1.01-1.10, \mathrm{P}=0.047$ ) resulted in an increased number of patients with CKD. In short-term observation the IQR increase in weekly $\mathrm{PM}_{2.5}$ concentration was associated with a $2 \%$ reduction in eGFR $(\mathrm{OR}=0.98,95 \% \mathrm{Cl} 0.97-0.99, \mathrm{P}=0.03)$

Conclusions: The effects of air pollution on renal function were observed. Long- and short-term exposure to elevated air pollution levels was associated with a decrease in eGFR. The main pollutant affecting the kidneys was $\mathrm{PM}_{2.5}$.

\section{Introduction}

Air quality was put in the spotlight since the severe air pollution event called the Great Smog of London. Retrospective medical reports in the following weeks estimated that 4,000 people had died as a direct result of the smog and 100,000 more were made ill by the smog's effects on the cardiovascular system and respiratory tract. Since then, it became clear that the adverse effects of air pollution are serious and the reduction of pollution should become a priority in social and health policy.

In recent years it has been established that air pollutants associated with the harmful effect on human health are particulate matter with a diameter of $2.5 \mathrm{~mm}$ or less $\left(\mathrm{PM}_{2.5}\right)$, particulate matter with a diameter of $10 \mathrm{~mm}$ or less $\left(\mathrm{PM}_{10}\right)$, sulfur dioxide $\left(\mathrm{SO}_{2}\right)$, and nitrogen dioxide $\left(\mathrm{NO}_{2}\right)$ [1]. Some of these components are formed directly as a result of fuel burning, while others emerge as a result of photochemical reactions that occur under the influence of ultraviolet radiation in the air.

Regardless of the source, according to the European Environment Agency, particulate matter contributes to the premature death of approximately 428,000 citizens of Europe every year [2]. There is a great deal of 
evidence in the literature for the short- and long-term adverse effects of air pollution on the cardiovascular and pulmonary systems [3-13]. The exact mechanisms associated with the impact of air pollution on the human body remain unclear. Air pollutants can activate inflammatory cells in the lungs, leading to the release of mediators, and stimulate alveolar receptors which causes an imbalance in the autonomic nervous system and neuroendocrine pathway. The second way is translocating of air pollution via pulmonary epithelium - pollutants enter into the blood circulation and affect the whole organism. The mentioned above processes lead to oxidative stress which is widely acknowledged as a factor for vascular dysfunction [14-16].

Although the topic of air pollution has been in the focus of researchers for many years, only a few studies assessing the long-term impact of air pollution on developing chronic kidney disease (CKD) have been reported in the literature [17-22]. The lack of major studies evaluating the long-term effects of air pollution on kidney function has led us to analyze this relationship. We also try to carried out to investigate the hypothesis indicating that we can observe not only the long-term but also the short-term impact of air pollution on renal function.

\section{Patients And Methods}

\subsection{Study participants}

We conducted a retrospective cross-sectional study on 26,985 patients referred for elective coronary angiography to the Department of Invasive Cardiology of the Medical University of Bialystok, Bialystok, Poland between 2007 and 2016. We excluded patients with acute coronary syndromes (ACS), coronary artery disease (CAD) and chronic heart failure (CHF) as those diseases affect renal function. Hemodialysis was also the exclusion criterion.

We included 8,288 patients admitted to scheduled coronary angiography for further analysis. The set of extracted variables included residence data, demographic data, medical history, and biochemical test results. In the analysis, we used data from patients registered and residential in the city of Bialystok (id commune 206101). Finally, our study cohort consisted of 3,554 patients [Figure 1].

CKD recognition was made according to KDIGO 2012 Clinical Practice Guideline for the Evaluation and Management of Chronic Kidney Disease. CKD was defined as the presence of kidney damage or an estimated glomerular filtration rate (eGFR) lower than $60 \mathrm{ml} / \mathrm{min} / 1.73 \mathrm{~m}^{2}$, persisting for three months or more. The eGFR rate was counted using CKD-EPI formulas [23].

\subsection{Pollution and weather conditions data}

The data of air pollution and gases were obtained from the Voivodeship Inspectorate for Environmental Protection from stations that are representative for the studied city (id commune 206101). In the analysis, we used the concentration of sulfur dioxide $\left(\mathrm{SO}_{2}\right)$, nitrogen dioxide $\left(\mathrm{NO}_{2}\right)$, and particulate matter with a diameter of $2.5 \mathrm{~mm}$ or less $\left(\mathrm{PM}_{2.5}\right)$ and $10 \mathrm{~mm}$ or less $\left(\mathrm{PM}_{10}\right)$. The data on the concentrations of gases 
(except 2013 for S02) and PMs were obtained from stations (international code (ID): PL0148A) and

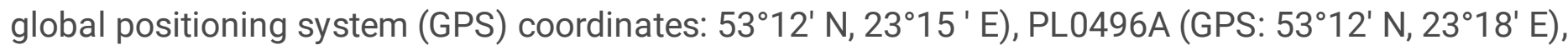

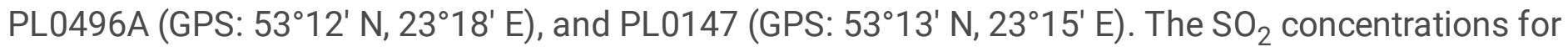
2013 were obtained from the suburban station (ID: PL0149A, GPS: $53^{\circ} 13^{\prime} \mathrm{N}, 2^{\circ} 22^{\prime} \mathrm{E}$ ).

The daily meteorological data, including mean temperature, the daily level of relative humidity, and mean atmospheric pressure were obtained from the Institute of Meteorology and Water Management. We used the data from station Ciolkowskiego Street (ID 353230295, GPS: $53^{\circ} 10^{\prime} \mathrm{N}, 23^{\circ} 16^{\prime} \mathrm{E}$ ). The study material lacked about $3.1 \%$ of data. The days with missing data were excluded from the analysis.

\subsection{Study design and statistical analysis}

We analyzed if short-term and long-term air pollution exposure was associated with renal function. To access the impact of air pollution we used lag distributed regression models that have been widely used in environmental epidemiology (detailed description belove). The multivariable logistic regression model was performed to access associations of air pollution and incidence of chronic kidney disease. The number of patients with CKD were defined as a dependent variable. The independent variables were concentrations of air pollution one year before admission. To control for the long-term trend and seasonal effects, we used a time-stratified model (simple indicator variables). We adjusted our model for day of the week, public holidays, clinical variables (including obesity, atrial fibrillation, hyperlipidemia, diabetes mellitus, arterial hypertension), atmospheric pressure, humidity and cubic spline function of mean daily temperature with 4 degrees of freedom. Results are reported for an increase in interquartile range concentration of air pollution and presented as odds ratio (OR) with $95 \% \mathrm{Cl}$ and scatter plots.

Linear regression analysis was performed to identify short-term associations between estimated glomerular filtration rate and concentration of particulate matter and gases. The eGFR CKD -EPI was assessed on admission and was defined as a dependent variable. The independent variables were concentrations of $\mathrm{NO}_{2}, \mathrm{SO}_{2}$, and PMs at days with LAG from 1 to 6 and mean concertation for week before admission. We estimated two statistical models: unadjusted linear model (without covariates) and linear model controlled for long term and seasonality, also adjusted for weather conditions and clinical variables including age, sex, obesity, atrial fibrillation, hyperlipidemia, diabetes mellitus, and arterial hypertension. The results are reported as beta coefficients ( $\beta$ ) and $95 \%$ confidence intervals (Cls) for renal function. We also estimated the log - linear regression model. The eGFR was assessed on admission and was defined as a dependent variable, the independent variables were weekly before admission concentrations of $\mathrm{NO}_{2}, \mathrm{SO}_{2}$, and $\mathrm{PMs}$. Model was model was adjusted for seasonality and long-time trends, weather conditions: temperature, humidity, atmospheric pressure, age, sex and clinical variables including obesity, atrial fibrillation, hyperlipidemia, diabetes mellitus, arterial hypertension. Results are reported for an increase in IQR of air pollution and presented as OR with $95 \% \mathrm{Cl}$ and scatter plots. The characteristics od studied population and weather conditions are presented as means with standard deviations (SD) for normally distributed continuous, as medians with interquartile ranges (IQR) for not normally distributed continuous variables and as the number of cases and percentage (for categorical 
variables). We used the Kolmogorov-Smirnov test to assess the distribution of variables. The correlations between daily air pollutants and eGFR were determined using Person's correlation. Data are presented as rank correlation (R) and scatter plots.

The threshold of statistical significance for all tests was set at $\mathrm{P}<0.05$. All analyses were performed using MS Excel (Microsoft, 2020, version 16.40, Redmond, WA, USA) and XL Stat (Addinsoft, 2020, version 2020.03.01, New York, NY, USA). The study protocol conformed to the ethical guidelines of the 1975 Declaration of Helsinki, was approved by the ethics committee of the Medical University of Bialystok (R-1-002/18/2019) and registered at ClinicalTrials.gov (Identifier: NCT04541498). Informed consent was obtained from all participants on admission to the hospital.

\section{Results}

Out of 26,985 patients admitted to the Department of Invasive Cardiology, a total of 3,554 patients were included into the final analysis. The median age was $66(1 Q=58 ; 3 Q=73)$ and men were in the majority $(53.2 \%, \mathrm{~N}=1891)$. Hypertension was present in over $80 \%$ of study participants $(83.5 \%, \mathrm{~N}=2966)$, hyperlipidemia in two thirds $(67.5 \%, \mathrm{~N}=2399)$, while diabetes and obesity in a quarter. Patients with atrial fibrillation accounted for $18.4 \%(\mathrm{~N}=653)$ of the investigated population. Paroxysmal AF was the most frequent form of the analyzed arrhythmia $(8.5 \%, \mathrm{~N}=303)$ [Table 1].

Chronic kidney disease (CKD) was approximately diagnosed in every fourth patient of the study population $(21.5 \%, \mathrm{~N}=764)$. The mean CKD -EPI eGFR $\left(\mathrm{mL} / \mathrm{min} \cdot 1.73 \mathrm{~m}^{2}\right)$ was $75.6(\mathrm{SD}=18.3)$. The majority of patients were characterized by eGFR in the range $60-90 \mathrm{ml} / \mathrm{min} / 1.73 \mathrm{~m}^{2}(56.1 \%, \mathrm{~N}=1933)$. The next largest group in terms of quantity were patients with eGFR in the range over $90 \mathrm{ml} / \mathrm{min} / 1.73 \mathrm{~m}^{2}$, that is $24.1 \%(\mathrm{~N}=858)$. There have been single cases of patients with eGFR under $30 \mathrm{ml} / \mathrm{min} / 1.73 \mathrm{~m}^{2}(1.5 \%$, $\mathrm{N}=54)$. Detailed characteristics of the kidney function in study subjects are provided in Table 2.

In our analysis, we took into account the concentrations of $\mathrm{PM}_{2.5}, \mathrm{PM}_{10}, \mathrm{NO}_{2}$, and $\mathrm{SO}_{2}$ from 2007 to 2016. The median daily concentration of $\mathrm{PM}_{2.5}$ was $10.9 \mu \mathrm{g} / \mathrm{m}^{3}(\mathrm{IQR}-15.9), \mathrm{PM}_{10}-15.6 \mu \mathrm{g} / \mathrm{m}^{3}(\mathrm{IQR}-$ 17.5), $\mathrm{NO}_{2}-13.1 \mu \mathrm{g} / \mathrm{m}^{3}$ (IQR - 7.7) and of $\mathrm{SO}_{2}-1.4 \mu \mathrm{g} / \mathrm{m}^{3}$ (IQR - 2.8) [Table 3]. Detailed characteristics of concentration of air pollution during analyzed years are provided in Table 3.

A moderate positive correlation was found between concentration of particulate matter and gases: $\mathrm{PM}_{10}$ vs. $\mathrm{SO}_{2}(\mathrm{R}=0.44, \mathrm{P}<0.001), \mathrm{PM}_{10}$ vs. $\mathrm{NO}_{2}(\mathrm{R}=0.53, \mathrm{P}<0.001), \mathrm{PM}_{2.5}$ vs. $\mathrm{SO}_{2}(\mathrm{R}=0.51, \mathrm{P}<0.001)$, and $\mathrm{PM}_{2.5}$ vs. $\mathrm{NO}_{2}\left(R=0.54, P<0.001\right.$. Moreover, a negative correlation was found between eGFR and $P M_{10}(R=-0.04$, $P=0.047), P_{2.5}(R=-0.05, P=0.02)$, and $\mathrm{SO}_{2}(R=-0.06, P=0.01)$, respectively [Table 4].

In the long-term increase annual average concertation of $\mathrm{PM}_{2.5}$ and $\mathrm{NO}_{2}$ resulted in an increased number of patients with chronic kidney. The odds ratio for yearly IQR increase of $\mathrm{PM}_{2.5}$ was $1.07(95 \% \mathrm{Cl} 1.01-$ 1.15, $\mathrm{P}=0.037)$, for $\mathrm{NO}_{2}$ it was $1.05(95 \% \mathrm{Cl} 1.01-1.10, \mathrm{P}=0.047)$ [Figure 2]. 
Table 5 presents the results of the linear regression analysis of the short-term associations between ambient air pollution and eGFR. The $P_{2.5}$ concentration at lag $5 \beta=-0.04(-0.08--0.01, P=0.02)$, lag $6 \beta=$ $-0.05(-0.09--0.01, P=0.01)$, and $\mathrm{SO}_{2}$ at $\operatorname{lag} 1 \beta=-0.05(-0.08--0.02, P=0.01)$ were associated with decreased eGFR. However, after the adjustment for covariates $\mathrm{PM}_{10}$ at lag 1 was significantly associated with decreased eGFR $\beta=-0.03(-0.07--0.01, P=0.04)$. In the weekly analysis, the $P_{2.5}$ concentration $\beta=$ $-0.063(-0.12--0.01 ; P=0.04)$ were associated with decreased eGFR [Table 5].

In the log linear regression model, IQR increase in weekly $\mathrm{PM}_{2.5}$ concentration was associated with a $2 \%$ reduction in eGFR $(\mathrm{OR}=0.98,95 \% \mathrm{Cl} 0.97-0.99, \mathrm{P}=0.03)$ [Figure 3].

\section{Discussion}

To our knowledge, this is the first study that focuses on the long- and short-term impact of air pollution on renal function. The main findings are as follows: the long-term effect of $\mathrm{PM}_{2.5}$ on kidney function was observed. In the short-term analysis, the effects of $\mathrm{NO}_{2}, \mathrm{SO}_{2}$, and PMs were observed and delayed in time up to one week.

Many studies reported geographic variation in the burden of chronic kidney disease. Differences were noted even after adjusting for diabetes mellitus, arterial hypertension, and obesity, which are considered to be major contributors to renal function worsening. This fact suggests that variation in the burden of CKD is likely due to factors other than these traditional risk factors [25]. One of them is air pollution, which was confirmed in our analysis. Similar results were reported in a few studies focused on the association between air pollution and kidney function. In a Taiwanese study increase in annual $10 \mu \mathrm{g} / \mathrm{m}^{3}$ concentration of PMs was associated with a 6\% higher risk of developing CKD (Hazard Ratio: 1.06, $95 \% \mathrm{Cl}: 1.02,1.10)$ [26]. Kim et al. investigated inverse relationships between air pollutants and eGFR. The annual interquartile range increase in $\mathrm{PM}_{10}$ and $\mathrm{NO}_{2}$ was related with a decrease in eGFR levels of 0.5 $(95 \% \mathrm{Cl}=-0.9-0.04)$ and $0.85(95 \% \mathrm{Cl}-1.4-0.3)$, respectively [27]. In a study conducted in Boston (Massachusetts, United States of America) a difference in eGFR level was associated with traffic-related air pollution. Comparing patients living $0.05 \mathrm{~km}$ vs. $1 \mathrm{~km}$ from a major roadway, the first group was associated with a $3.9 \mathrm{~mL} / \mathrm{min} / 1.73 \mathrm{~m} 2$ lower eGFR (95\%Cl: 1.0-6.7; $\mathrm{p}=0.007)$ than the latter one [28]. In a population-based cohort of veterans in the USA, a $10-\mu \mathrm{g} / \mathrm{m}^{3}$ increase in $\mathrm{PM}_{2.5}$ concentration was associated with increased risk of CKD (Hazard ratio=1.21; 95\% Cl 1.14-1.29) [29].

Potential mechanisms for associations between air pollution and renal function are not clear. In our opinion, long-term effects can be associated with an adverse influence on the cardiovascular system, peripheral arterial disease, progression of hypertension, and diabetes - mainly glucose intolerance. Decreased insulin sensitivity can negatively influence kidneys and promote CKD [30-35]. Additionally, we speculate that the short-term mechanism of air pollution-related eGFR decrease may be similar to the pathway of cardiovascular diseases induced by air pollution. There are a few ways that inhaled pollutants could affect renal function. 
The first way is a direct impact on the kidneys. Due to the large alveolar surface, air pollutants translocate via pulmonary tract and enter the blood circulation, which leads to oxidative stress. Particulate matter exposure may also progress glomerulosclerosis and tubular damage. In kidneys, pollutions can interact with tissue components to promote pathological effects. The second one explains its influence via an imbalance in the autonomic nervous system and neuroendocrine pathway. It results in increased systolic blood pressure and pulse rate. Pollutants stimulate alveolar receptors that activate autonomic reflex arcs influencing kidney vascular homeostasis and provoking pulmonary inflammation, which may then lead to systemic inflammation [36,37]. In the literature, we can find some indirect evidence supporting this hypothesis. In Miller et al. study, inhaled gold nanoparticles entered the bloodstream via pulmonary alveoli and were detected in the urine after the exposure, which partly proofs the concept of a possible influence of inhaled air pollution on the kidneys [38]. Those finding lead to one more potential mechanism of eGFR decrease reported in our study. In the mixture of air pollution, there are also various heavy metals and polycyclic aromatic hydrocarbons. Exposure to chemicals directly impairs renal function [39].

The name of the region, in which the analyzed city is located, is widely known as the Green Lungs of Poland. It is situated in the north-eastern part of Poland and owes its name to the surroundings of the national parks and low industrialization. However, despite their unique location, the characteristics of the cities contribute to an increased level of air pollution, with its main origin coming from linear sources, related to vehicles and the transit traffic from Northern and Eastern Europe to Central Europe. Some studies claim that diesel exhausts are the main sources of $\mathrm{PM}_{2.5}$-bound $\mathrm{PAH} . \mathrm{PM}_{2.5}$ has various health effects depending on its source. Diesel exhaust particles (DEP) are responsible for the highest generation of intracellular reactive oxygen species (ROS). Additionally, they alter vascular transcription and represent the highest mutagenic activity. Generation of ROS is crucial and can influences both - long- and shortterm effects of air pollutants on renal function [40-42].

This study has several limitations. Cohort participants were Caucasian based in north-eastern Poland; therefore, in our opinion, the findings may not be applicable to other populations. Secondly, the effect of smoking was not analyzed in our research which may be the main limitation of this study. Smoking is considered to be one of the main risk factors for renal failure and the effect of air pollution may also cover the outcomes of smoking. In our opinion, an additional limitation of our work is also underdeveloped air pollution monitoring system of the study area as well as the lack of constant monitoring of ultrafine PMs and heavy metals.

Regardless of those limitations, we conclude that not only long term but also short-term exposure to air pollutants is associated with lowering of kidney function. However, further studies are required to understand the mechanism of affecting renal function by exposure to air pollution and other environmental factors like soil and water pollutions.

\section{Conclusions}


The effects of air pollution on renal function were observed. Long- and short-term exposure to elevated air pollution levels was associated with a decrease in eGFR. The main pollutant affecting the kidneys was $\mathrm{PM}_{2.5}$.

\section{Declarations}

Author Contributions: Conceptualization and methodology, L.K., J. M. and H. B - G.; methodology and data curation, L.K.; formal analysis and investigation L.K, H. B - G.; writing-original draft preparation L.K., J.M.; writing-review and editing, L.K., J. M. and H. B - G. and S.D.; supervision, H. B -G and S.D. All authors have read and agreed to the published version of the manuscript.

Funding: This research received no external funding.

Conflicts of Interest: The authors declare no conflict of interest.

Data availability: The data that support the findings of this study are available from the corresponding author on request.

\section{References}

[1] WHO. Ambient (outdoor) air quality and health. World Health Organization 2018. [Internet] Accessed September, 1, 2020. Available from: https://www.who.int/news-room/fact-sheets/detail/ambient(outdoor)-air-quality-and-health/.

[2] Air Quality in Europe - 2017 report. European Environment Agency [Internet] Accessed September, 1, 2020. Available from https://www.eea.europa.eu/publications/air-quality-in-europe-2017/.

[3] Rasche $M$, Walther $M$, Schiffner $R$, et al. Rapid increases in nitrogen oxides are associated with acute myocardial infarction: A case-crossover study. Eur J Prev Cardiol. 2018;25(16):1707-1716.

DOI:10.1177/2047487318755804

[4] Butland BK, Atkinson RW, Milojevic A, et al. Myocardial infarction, ST-elevation and non-ST-elevation myocardial infarction and modelled daily pollution concentrations: a case-crossover analysis of MINAP data. Open Heart. 2016;3(2):e000429. DOI:10.1136/openhrt-2016-000429

[5] Buszman PE, Derbisz K, Kwasiborski P, et al. Impact of air pollution on hospital patients admitted with ST- and non-ST-segment elevation myocardial infarction in heavily polluted cities within the European Union. Cardiol J. 2018;10. doi:10.5603/CJ.a2018.0156

[6] Akbarzadeh MA, Khaheshi I, Sharifi A, et al. The association between exposure to air pollutants including PM10, PM2.5, ozone, carbon monoxide, sulfur dioxide, and nitrogen dioxide concentration and the relative risk of developing STEMI: A case-crossover design. [7] Environ Res. 2018;161:299-303. DOI:10.1016/j.envres.2017.11.020 
Amsalu E, Wang T, Li H, et al. Acute effects of fine particulate matter (PM2.5) on hospital admissions for cardiovascular disease in Beijing, China: a time-series study. Environ Health. 2019;18(1):70. DOI:

10.1186/s12940-019-0506-2

[8] Kuźma Ł, Pogorzelski S, Struniawski K, et al. Effect of air pollution on the number of hospital admissions for acute coronary syndrome in elderly patients. Pol Arch Intern Med. 2020;130(1): 38-46. DOI:10.20452/pamw.15064

[9] Ye X, Peng L, Kan H, et al. Acute Effects of Particulate Air Pollution on the Incidence of Coronary Heart Disease in Shanghai, China. 2016;11(3):e0151119. DOI:10.1371/journal.pone.0151119

[10] Pope CA 3rd, Muhlestein JB, May HT, et al. Ischemic heart disease events triggered by short-term exposure to fine particulate air pollution. Circulation. 2006;114(23):2443-2448.

DOI:10.1161/CIRCULATIONAHA.106.636977

[11] Hong E, Lee S, Kim GB, et al. Effects of Environmental Air Pollution on Pulmonary Function Level of Residents in Korean Industrial Complexes. Int J Environ Res Public Health. 2018;15(5):834. Published 2018 Apr 24. DOI: 10.3390/ijerph15050834

[12] Ko FW, Hui DS. Outdoor air pollution: impact on chronic obstructive pulmonary disease patients. Curr Opin Pulm Med. 2009;15(2):150-157. DOI: 10.1097/MCP.0b013e32832185ee

[13] Wu S, Ni Y, Li H, et al. Short-term exposure to high ambient air pollution increases airway inflammation and respiratory symptoms in chronic obstructive pulmonary disease patients in Beijing, China. Environ Int. 2016;94:76-82. DOI: 10.1016/j.envint.2016.05.004

[14] Miller MR, Shaw CA, Langrish JP. From particles to patients: oxidative stress and the cardiovascular effects of air pollution. Future Cardiol. 2012;8(4):577-602. DOI:10.2217/fca.12.43

[15] Fiordelisi, A., Piscitelli, P., Trimarco B. et al. The mechanisms of air pollution and particulate matter in cardiovascular diseases. Heart Fail Rev. 2017; 22, 337-347. DOI: 10.1007/s10741-017-9606-7

[16] Pope CA The Expanding Role of Air Pollution in Cardiovascular Disease Circulation. 2009;119:30503052. DOI: 10.1161/CIRCULATIONAHA.109.870279

[17] Chan TC, Zhang Z, Lin BC, et al. Long-Term Exposure to Ambient Fine Particulate Matter and Chronic Kidney Disease: A Cohort Study. Environ Health Perspect. 2018;126(10):107002. DOI:10.1289/EHP3304

[18] Bragg-Gresham J, Morgenstern H, McClellan W, et al. County-level air quality and the prevalence of diagnosed chronic kidney disease in the US Medicare population. PLoS One. 2018;13(7):e0200612. Published 2018 Jul 31. DOI:10.1371/journal.pone.0200612

[19] Bowe B, Xie Y, Li T, et al.. Estimates of the 2016 global burden of kidney disease attributable to ambient fine particulate matter air pollution. BMJ Open. 2019;9(5):e022450. Published 2019 May 9. 
DOI:10.1136/bmjopen-2018-022450

[20] Chan TC, Zhang Z, Lin BC, et al. Long-Term Exposure to Ambient Fine Particulate Matter and Chronic Kidney Disease: A Cohort Study. Environ Health Perspect. 2018;126(10):107002. DOI:10.1289/EHP3304

[21] Chen SY, Chu DC, Lee JH, et al. Traffic-related air pollution associated with chronic kidney disease among elderly residents in Taipei City. Environ Pollut. 2018;234:838-845 DOI:

10.1016/j.envpol.2017.11.084

[22] Yang YR, Chen YM, Chen SY, Chan CC. Associations between Long-Term Particulate Matter Exposure and Adult Renal Function in the Taipei Metropolis. Environ Health Perspect. 2017 Apr;125(4):602-607. doi: 10.1289/EHP302

[23] KDIGO 2012 clinical practice guideline for the evaluation and management of chronic kidney disease. Kidney Int Suppl, 3 (2013), pp. 1-150 [Internet] Accessed September, 1, 2020. Available from:

https://kdigo.org/wp-content/uploads/2017/02/KDIGO_2012_CKD_GL.pdf

[24] World Health Organization, Ambient (outdoor) air quality and health (updated May 2, 2018). World Health Organization [Internet] Accessed September, 1, 2020. Available from: https://www.who.int/newsroom/fact-sheets/detail/ambient-(outdoor)-air-quality-and-health

[25] Mills KT, Xu Y, Zhang W A, et al. A systematic analysis of worldwide population-based data on the global burden of chronic kidney disease in 2010. Kidney Int 88: 950-957, 2015 DOI: 10.1038/ki.2015.230

[26] Chan TC, Zhang Z, Lin BC, et al. Long-Term Exposure to Ambient Fine Particulate Matter and Chronic Kidney Disease: A Cohort Study. Environ Health Perspect. 2018;126(10):107002. DOI:10.1289/EHP3304

[27] Kim HJ, Min JY, Seo YS, et al. Association between exposure to ambient air pollution and renal function in Korean adults. Ann Occup Environ Med. 2018;30:14. DOI:10.1186/s40557-018-0226-z

[28] Lue SH, Wellenius GA, Wilker EH, et al. Residential proximity to major roadways and renal function. J Epidemiol Community Health. 2013;67:629-634. DOI: 10.1136/jech-2012-202307.

[29] Bowe B, Xie Y, Li T, et al. Particulate Matter Air Pollution and the Risk of Incident CKD and Progression to ESRD. J Am Soc Nephrol. 2018;29(1):218-230. DOI:10.1681/ASN.2017030253

[30] Eze IC, Hemkens LG, Bucher $\mathrm{H}$, et al. Association between ambient air pollution and diabetes mellitus in Europe and North America: systematic review and meta-analysis. Environ Health Perspect. 2015 May;123(5):381-9. DOI: 10.1289/ehp.1307823

[31] Liu F, Chen G, Huo W, et al. Associations between long-term exposure to ambient air pollution and risk of type 2 diabetes mellitus: A systematic review and meta-analysis. Environ Pollut. 2019 Sep;252(Pt B):1235-1245. DOI: 10.1016/j.envpol.2019.06.033 
[32] Soldevila Bacardit N, Vinyoles Bargalló E, et al. Contaminación atmosférica, riesgo cardiovascular e hipertensión arterial [Air pollution, cardiovascular risk and hypertension]. Hipertens Riesgo Vasc. 2018 Oct-Dec;35(4):177-184. Spanish. DOI: 10.1016/j.hipert.2018.03.001

[33] Sanidas E, Papadopoulos DP, Grassos H, et al. Air pollution and arterial hypertension. A new risk factor is in the air. J Am Soc Hypertens. 2017 Nov;11(11):709-715. DOI: 10.1016/j.jash.2017.09.008

[34] Yang BY, Qian Z, Hoard SW, et al. Global association between ambient air pollution and blood pressure: A systematic review and meta-analysis. Environ Pollut. 2018 Apr;235:576-588. DOI: 10.1016/j.envpol.2018.01.001

[35] Fuks KB, Weinmayr G, Basagaña X, et al. Long-term exposure to ambient air pollution and traffic noise and incident hypertension in seven cohorts of the European study of cohorts for air pollution effects (ESCAPE). Eur Heart J. 2017 Apr 1;38(13):983-990. DOI: 10.1093/eurheartj/ehw413

[36] Almetwally AA, Bin-Jumah M, Allam AA. Ambient air pollution and its influence on human health and welfare: an overview. Environ Sci Pollut Res Int. 2020 Jul;27(20):24815-24830. DOI:10.1007/s11356-02009042-2

[37] Niemann B, Rohrbach S, Miller MR. Oxidative Stress and Cardiovascular Risk: Obesity, Diabetes, Smoking, and Pollution: Part 3 of a 3-Part Series. J Am Coll Cardiol. 2017 Jul 11;70(2):230-251. DOI:10.1016/j.jacc.2017.05.043

[38] Miller MR, Raftis JB, Langrish JP. Inhaled Nanoparticles Accumulate at Sites of Vascular Disease. ACS Nano. 2017 May 23;11(5):4542-4552. DOI:10.1021/acsnano.6b08551

[39] Kataria A, Trasande L, Trachtman $\mathrm{H}$. The effects of environmental chemicals on renal function. Nat Rev Nephrol. 2015. 11(10):610-625, DOI: 10.1038/nrneph.2015.94

[40] Park CG, Cho HK, Shin HJ. Comparison of Mutagenic Activities of Various Ultra-Fine Particles. Toxicol Res. 2018 Apr;34(2):163-172. DOI: 10.5487/TR.2018.34.2.163

[41] Cho HK, Park CG, Shin HJ. Comparison of the in vitro toxicological activity of various particulate matter. Toxicol Ind Health. 2018 Feb;34(2):99-109. DOI: 10.1177/0748233717749694

[42] Campen MJ, Lund AK, Doyle-Eisele ML. A comparison of vascular effects from complex and individual air pollutants indicates a role for monoxide gases and volatile hydrocarbons. Environ Health Perspect. 2010 Jul;118(7):921-7. DOI: 10.1289/ehp.0901207

\section{Tables}

Table 1. Characteristics of the study participants. 
All study participants, (N)

(3554)

Male, \% (N)

$53.2(1891$

Age (years), median (Quartiles)

$66(1 \mathrm{Q}=58 ; 3 \mathrm{Q}=73)$

Elderly > 65 years old, \% (N)

54.8 (1948)

CCS (class), median (Quartiles)

$2(1 \mathrm{Q}=2 ; 3 \mathrm{Q}=2)$

Arterial hypertension, \% (N)

$83.5(2966)$

Obesity, \% (N)

34.1 (1212)

BMI $\left(\mathrm{kg} / \mathrm{m}^{2}\right)$, mean (SD)

$28.9(4.7)$

Hyperlipidemia, \% (N)

67.5 (2399)

Serum LDL cholesterol concentration (mg/dl), mean (SD) 105.0 (39.6)

Serum HDL cholesterol concentration (mg/dl), mean (SD)

$48.2(13.4)$

Total serum cholesterol concentration $(\mathrm{mg} / \mathrm{dl})$, mean, (SD)

Diabetes mellitus type $2, \%(\mathrm{~N})$

$177.9(42.7)$

$26.3(936)$

Fasting blood glucose concentration (mg/dl), mean, (SD)

$114.5(42.3)$

Atrial fibrillation, \% (N)

$18.4(653)$

Paroxysmal atrial fibrillation, \% (N)

$8.5(303)$

Persistent atrial fibrillation, \% (N)

$7.7(276)$

Permanent atrial fibrillation, \% (N)

$2.0(71)$

Hospitalization outcomes

Patients qualified for conservative management, \% (N)

$64.1(2279)$

Patients qualified for the Heart-Team consultation, \% (N)

$13.6(482)$

Patients qualified for $\mathrm{PCl}, \%(\mathrm{~N})$

$22.3(793)$

Abbreviations: 1Q, 1st quartile; 3Q, 3rd quartile; CCS, Canadian Cardiovascular Society Angina Grading Scale; $\mathrm{PCl}$, percutaneous coronary intervention

Table 2. Kidney function in the study participants. 


\begin{tabular}{|ll|}
\hline All study participants, $(\mathrm{N})$ & $\mathbf{( 3 5 5 4 )}$ \\
\hline Chronic kidney disease, \% (N) & $21.5(764)$ \\
\hline Creatinine $(\mathrm{mg} / \mathrm{dL})$, mean, (SD) & $0.98(0.35)$ \\
\hline eGFR $\left(\mathrm{mL} / \mathrm{min} \cdot 1.73 \mathrm{~m}^{2}\right)$, mean, (SD) & $75.6(18.3)$ \\
\hline Patients with eGFR $>90 \mathrm{~mL} / \mathrm{min} \cdot 1.73 \mathrm{~m}^{2}, \%(\mathrm{~N})$ & $24.1(858)$ \\
\hline Patients with eGFR $60-90 \mathrm{~mL} / \mathrm{min} \cdot 1.73 \mathrm{~m}^{2}, \%(\mathrm{~N})$ & $56.1(1933)$ \\
\hline Patients with eGFR $45-60 \mathrm{~mL} / \mathrm{min} \cdot 1.73 \mathrm{~m}^{2}, \%(\mathrm{~N})$ & $12.3(436)$ \\
\hline Patients with eGFR $30-45 \mathrm{~mL} / \mathrm{min} \cdot 1.73 \mathrm{~m}^{2}, \%(\mathrm{~N})$ & $5.9(211)$ \\
\hline Patients with eGFR $15-30 \mathrm{~mL} / \mathrm{min} \cdot 1.73 \mathrm{~m}^{2}, \%(\mathrm{~N})$ & $1.2(43)$ \\
\hline Patients with eGFR $<15 \mathrm{~mL} / \mathrm{min} \cdot 1.73 \mathrm{~m}^{2}, \%(\mathrm{~N})$ & $0.3(11)$ \\
\hline
\end{tabular}

Abbreviations: eGFR, estimated glomerular filtration rate.

Table 3. Statistics for concentrations of air pollutants and weather conditions in the studied region. 


\begin{tabular}{|c|c|c|c|c|c|c|c|}
\hline & $\begin{array}{l}\mathrm{NO}_{2} \\
\mu \mathrm{g} / \mathrm{m}^{3}\end{array}$ & $\begin{array}{l}\mathrm{SO}_{2} \\
\mu \mathrm{g} / \mathrm{m}^{3}\end{array}$ & $\begin{array}{l}\mathrm{PM}_{2.5} \\
\mu \mathrm{g} / \mathrm{m}^{3}\end{array}$ & $\begin{array}{l}\mathrm{PM}_{10} \\
\mu \mathrm{g} / \mathrm{m}^{3}\end{array}$ & Temp. ${ }^{\circ} \mathrm{C}$ & $\begin{array}{l}\text { Hum. } \\
(\%)\end{array}$ & $\begin{array}{l}\text { Atm. } \\
\text { (hPa.) }\end{array}$ \\
\hline $\begin{array}{l}\text { 2007; } \\
\text { mean (SD) }\end{array}$ & $\begin{array}{l}14.9 \\
(6.6)\end{array}$ & $4.0(3.0)$ & N/D & $\begin{array}{l}24.1 \\
(12.1)\end{array}$ & $8.0(6.9)$ & $\begin{array}{l}81.5 \\
(10.9)\end{array}$ & $\begin{array}{l}1014.7 \\
(9.9)\end{array}$ \\
\hline $\begin{array}{l}\text { 2008; } \\
\text { mean (SD) }\end{array}$ & $\begin{array}{l}14.5 \\
(6.64)\end{array}$ & $2.6(3.0)$ & $N / D$ & $\begin{array}{l}23.9 \\
(13.8)\end{array}$ & $8.2(7.1)$ & $\begin{array}{l}81.8 \\
(11.1)\end{array}$ & $\begin{array}{l}1015.0 \\
(9.9)\end{array}$ \\
\hline $\begin{array}{l}\text { 2009; } \\
\text { mean (SD) }\end{array}$ & $\begin{array}{l}14.3 \\
(7.1)\end{array}$ & $1.5(3.8)$ & $\begin{array}{l}18.7 \\
(11.3)\end{array}$ & $\begin{array}{l}26.4 \\
(25.5)\end{array}$ & $7.2(8.6)$ & $\begin{array}{l}83.6 \\
(12.8)\end{array}$ & $\begin{array}{l}1014.8 \\
(7.6)\end{array}$ \\
\hline $\begin{array}{l}\text { 2010; } \\
\text { mean (SD) }\end{array}$ & $\begin{array}{l}15.1 \\
(7.0)\end{array}$ & $3.6(3.6)$ & $\begin{array}{l}23.7 \\
(17.1)\end{array}$ & $\begin{array}{l}27.7 \\
(17.5)\end{array}$ & $6.8(10.5)$ & $\begin{array}{l}83.7 \\
(10.7)\end{array}$ & $\begin{array}{l}1013.7 \\
(9.0)\end{array}$ \\
\hline $\begin{array}{l}\text { 2011; } \\
\text { mean (SD) }\end{array}$ & $\begin{array}{l}16.0 \\
(7.6)\end{array}$ & $3.7(4.2)$ & $\begin{array}{l}20.9 \\
(16.2)\end{array}$ & $\begin{array}{l}33.3 \\
(23.5)\end{array}$ & 7.7 (8.7) & $\begin{array}{l}81.7 \\
(11.9)\end{array}$ & $\begin{array}{l}1017.1 \\
(8.4)\end{array}$ \\
\hline $\begin{array}{l}\text { 2012; } \\
\text { mean (SD) }\end{array}$ & $\begin{array}{l}14.6 \\
(6.5)\end{array}$ & $3.3(3.6)$ & $\begin{array}{l}22.3 \\
(18.3)\end{array}$ & $\begin{array}{l}31.0 \\
(23.2)\end{array}$ & $7.1(9.8)$ & $\begin{array}{l}83.8 \\
(11.5)\end{array}$ & $\begin{array}{l}1015.4 \\
(9.4)\end{array}$ \\
\hline $\begin{array}{l}\text { 2013; } \\
\text { mean (SD) }\end{array}$ & $\begin{array}{l}14.4 \\
(6.1)\end{array}$ & $3.2(2.3)$ & $\begin{array}{l}19.3 \\
(12.4)\end{array}$ & $\begin{array}{l}26.9 \\
(14.9)\end{array}$ & $7.6(8.8)$ & $\begin{array}{l}82.6 \\
(12.0)\end{array}$ & $\begin{array}{l}1015.4 \\
(7.8)\end{array}$ \\
\hline $\begin{array}{l}\text { 2014; } \\
\text { mean (SD) }\end{array}$ & $\begin{array}{l}13.7 \\
(6.2)\end{array}$ & $4.3(3.1)$ & $\begin{array}{l}21.9 \\
(14.3)\end{array}$ & $\begin{array}{l}30.2 \\
(17.1)\end{array}$ & $8.1(8.6)$ & $\begin{array}{l}78.9 \\
(12.0)\end{array}$ & $\begin{array}{l}1016.6 \\
(7.5)\end{array}$ \\
\hline $\begin{array}{l}\text { 2015; } \\
\text { mean (SD) }\end{array}$ & $\begin{array}{l}14.9 \\
(6.7)\end{array}$ & $4.1(2.0)$ & $\begin{array}{l}19.1 \\
(14.3)\end{array}$ & $\begin{array}{l}29.2 \\
(19.7)\end{array}$ & $8.7(7.5)$ & $\begin{array}{l}76.6 \\
(12.9)\end{array}$ & $\begin{array}{l}1017.4 \\
(9.5)\end{array}$ \\
\hline $\begin{array}{l}\text { 2016; } \\
\text { mean (SD) }\end{array}$ & $\begin{array}{l}13.5 \\
(5.6)\end{array}$ & $3.2(1.3)$ & $\begin{array}{l}19.0 \\
(12.6)\end{array}$ & $\begin{array}{l}24.0 \\
(13.6)\end{array}$ & $8.0(8.3)$ & $\begin{array}{l}79.9 \\
(10.9)\end{array}$ & $\begin{array}{l}1016.3 \\
(8.2)\end{array}$ \\
\hline $\begin{array}{l}\text { Median } \\
\text { (IQR) }\end{array}$ & $\begin{array}{l}13.1 \\
(7.7)\end{array}$ & $1.4(2.8)$ & $\begin{array}{l}10.9 \\
(15.9)\end{array}$ & $\begin{array}{l}15.6 \\
(17.5)\end{array}$ & $7.8(6.2)$ & $\begin{array}{l}83.1 \\
(7.8)\end{array}$ & $\begin{array}{l}1015.5 \\
(11)\end{array}$ \\
\hline
\end{tabular}

Abbreviations: IQR, interquartile range; $\mathrm{N} / \mathrm{A}$, not available; $\mathrm{NO}_{2}$, nitrogen dioxide; $\mathrm{PM}_{2.5}$, particulate matter with a diameter of $2.5 \mathrm{~mm}$ or less; $\mathrm{PM}_{10}$, particulate matter with a diameter of $10 \mathrm{~mm}$ or less; SD, standard deviation; $\mathrm{SO}_{2}$, sulfur dioxide; 
Table 4. Person's correlations between eGFR at admission and air pollution concentration.

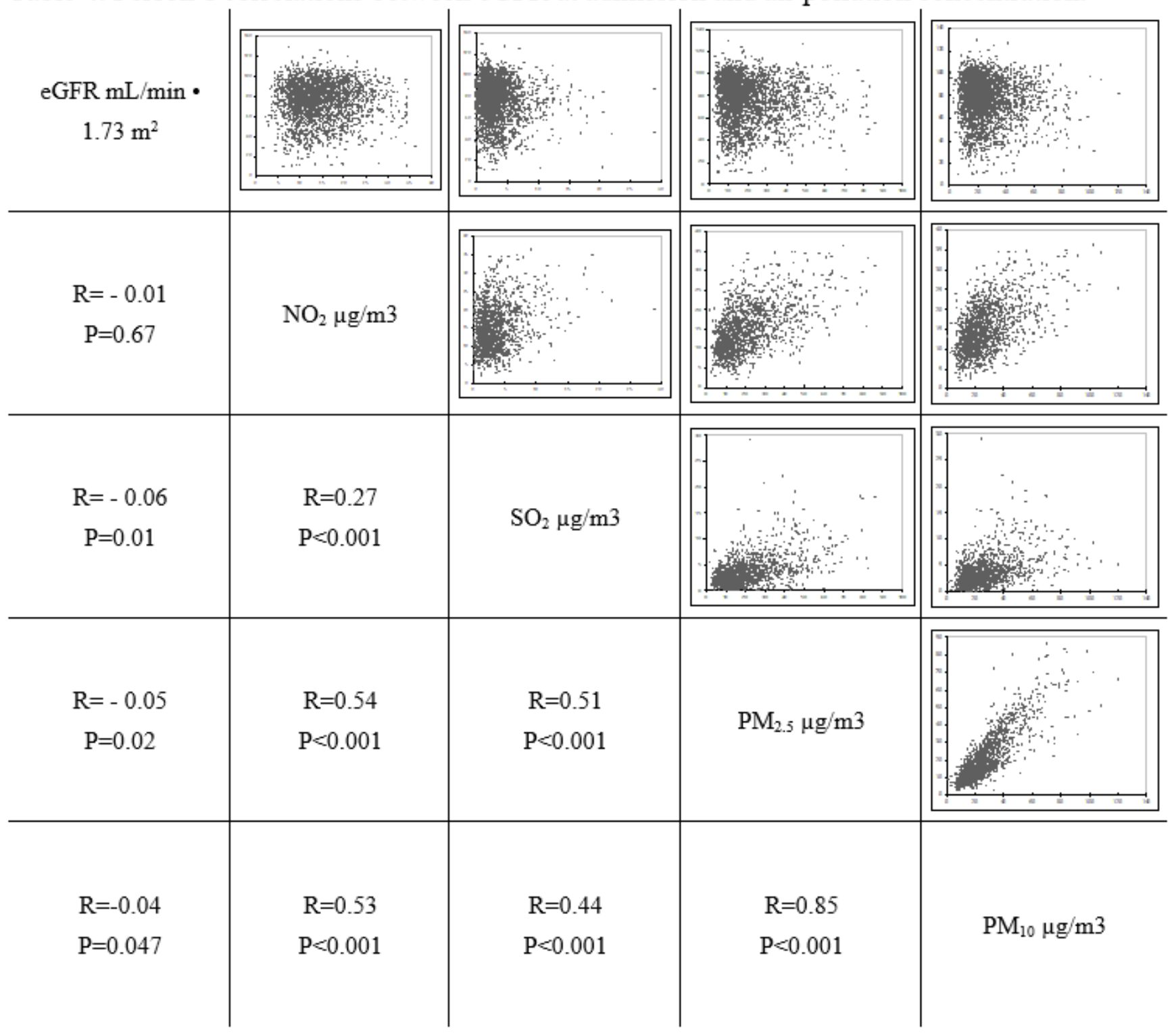

Abbreviations: eGFR, estimated glomerular filtration rate; NO2, nitrogen dioxide; PM2.5, particulate matter with a diameter of $2.5 \mu \mathrm{m}$ or less; PM10, particulate matter with a diameter of $10 \mu \mathrm{m}$ or less; SO2, sulfur dioxide.

Table 5. Linear regression model. Effect of air pollution on estimated glomerular filtration rate. 


\begin{tabular}{|c|c|c|c|c|}
\hline Variables & Unadjusted Model & & Adjusted Model $^{\star}$ & \\
\hline $\mathrm{NO}_{2}$ & $\beta(95 \% \mathrm{Cl})$ & $P$ & $\beta(95 \% \mathrm{Cl})$ & $P$ \\
\hline LAG 1 & $-0.01(-0.03-0.03)$ & 0.97 & $-0.01(-0.04-0.03)$ & 0.76 \\
\hline LAG 2 & $-0.02(-0.06-0.01)$ & 0.18 & $-0.03(-0.06-0.00)$ & 0.08 \\
\hline LAG 3 & $0.02(-0.08-0.12)$ & 0.72 & $-0.00(-0.03-0.03)$ & 0.97 \\
\hline LAG 4 & $0.03(-0.06-0.13)$ & 0.52 & $0.01(-0.03-0.04)$ & 0.68 \\
\hline LAG 5 & $-0.01(-0.04-0.03)$ & 0.67 & $-0.01(-0.04-0.02)$ & 0.61 \\
\hline LAG 6 & $-0.03(-0.06-0.00)$ & 0.07 & $-0.03(-0.06-0.0)$ & 0.06 \\
\hline Weekly & $-0.02(-0.16-0.16)$ & 0.98 & $0.04(-0.91-0.17)$ & 0.54 \\
\hline \multicolumn{5}{|l|}{$\mathrm{SO}_{2}$} \\
\hline LAG 1 & $-0.05(-0.08--0.02)$ & 0.01 & $-0.24(-0.4--0.09)$ & 0.01 \\
\hline LAG 2 & $-0.02(-0.06-0.01)$ & 0.19 & $-0.02(-0.06-0.01)$ & 0.14 \\
\hline LAG 3 & $0.01(-0.02-0.04)$ & 0.56 & $0.01(-0.02-0.04)$ & 0.52 \\
\hline LAG 4 & $-0.03(-0.23-0.17)$ & 0.77 & $-0.01(-0.03-0.03)$ & 0.86 \\
\hline LAG 5 & $-0.09(-0.28-0.10)$ & 0.35 & $-0.02(-0.05-0.02)$ & 0.36 \\
\hline LAG 6 & $0.00(-0.03-0.03)$ & 0.95 & $-0.00(-0.03-0.03)$ & 0.93 \\
\hline Weekly & $-0.13(-0.40-0.16)$ & 0.35 & $0.09(-0.13-0.31)$ & 0.41 \\
\hline \multicolumn{5}{|l|}{$\mathrm{PM}_{2.5}$} \\
\hline LAG 1 & $-0.03(-0.06-0.01)$ & 0.14 & $-0.03(-0.07-0.01)$ & 0.07 \\
\hline LAG 2 & $-0.02(-0.06-0.02)$ & 0.35 & $-0.03(-0.06-0.01)$ & 0.16 \\
\hline LAG 3 & $-0.01(-0.04-0.03)$ & 0.74 & $-0.01(-0.04-0.03)$ & 0.75 \\
\hline LAG 4 & $-0.04(-0.09-0.01)$ & 0.13 & $-0.03(-0.06-0.01)$ & 0.17 \\
\hline LAG 5 & $-0.04(-0.08--0.01)$ & 0.02 & $-0.04(-0.08--0.01)$ & 0.02 \\
\hline LAG 6 & $-0.05(-0.09--0.01)$ & 0.01 & $-0.05(-0.09--0.01)$ & 0.01 \\
\hline Weekly & $-0.03(-0.07-0.01)$ & 0.07 & $-0.63(-0.12--0.01)$ & 0.04 \\
\hline \multicolumn{5}{|l|}{$\mathrm{PM}_{10}$} \\
\hline LAG 1 & $-0.03(-0.06-0.01)$ & 0.07 & $-0.03(-0.07-0.01)$ & 0.04 \\
\hline LAG 2 & $-0.01(-0.03-0.03)$ & 0.97 & $-0.01(-0.05-0.03)$ & 0.57 \\
\hline
\end{tabular}




\begin{tabular}{|ccccc|} 
LAG 3 & $0.02(-0.01-0.06)$ & 0.19 & $0.02(-0.01-0.06)$ & 0.18 \\
LAG 4 & $0.01(-0.03-0.03)$ & 0.90 & $0.01(-0.03-0.04)$ & 0.91 \\
LAG 5 & $-0.01(-0.05-0.02)$ & 0.41 & $-0.01(-0.04-0.02)$ & 0.42 \\
LAG 6 & $-0.02(-0.06-0.01)$ & 0.16 & $-0.02(-0.05-0.01)$ & 0.15 \\
Weekly & $0.03(-0.06-0.04)$ & 0.75 & $0.21(-0.01-0.05)$ & 0.14 \\
\hline & & & & \\
\hline
\end{tabular}

*Model was adjusted for age, sex, clinical variables including obesity, atrial fibrillation, hyperlipidemia, diabetes mellitus and arterial hypertension

Abbreviations: $\mathrm{Cl}$, confidence interval; $\mathrm{NO}_{2}$, nitrogen dioxide; $\mathrm{PM}_{2.5}$, particulate matter with a diameter of $2.5 \mathrm{~mm}$ or less; $\mathrm{PM}_{10}$, particulate matter with a diameter of $10 \mathrm{~mm}$ or less; $\mathrm{SO}_{2}$, sulfur dioxide

\section{Figures}

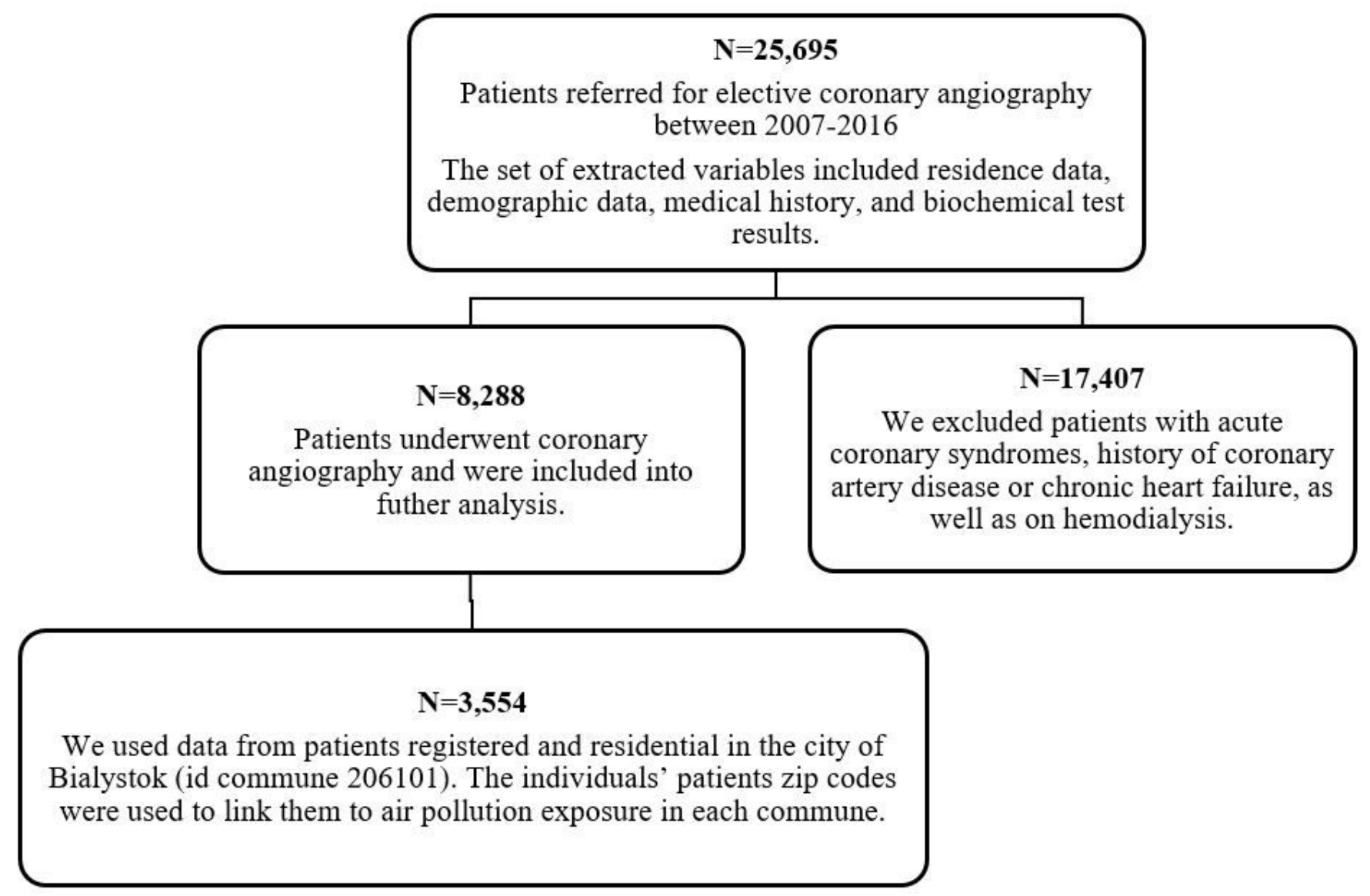

\section{Figure 1}

Flow diagram of study participants selection. 


$\begin{array}{lcccc} & \begin{array}{c}\text { Odds } \\ \text { ratio }\end{array} & \begin{array}{c}\text { Lower } \\ \text { limit }\end{array} & \begin{array}{c}\text { Upper } \\ \text { limit }\end{array} & \text { p-Value } \\ \mathrm{NO}_{2} & 1.05 & 1.01 & 1.1 & 0.047 \\ \mathrm{SO}_{2} & 1.01 & 0.96 & 1.07 & 0.60 \\ \mathrm{PM}_{10} & 1.05 & 0.99 & 1.11 & 0.13 \\ \mathrm{PM}_{2.5} & 1.07 & 1.01 & 1.15 & 0.037\end{array}$

Model was model was adjusted for seasonality and long-time trends, weather conditions: temperature, humidity, atmospheric pressure, age, sex, and clinical variables including obesity, atrial fibrillation, hyperlipidemia, diabetes mellitus, arterial hypertension.

Abbreviations: $\mathrm{NO}_{2}$, nitrogen dioxide; $\mathrm{PM}_{2.5}$, particulate matter with a diameter of $2.5 \mu \mathrm{m}$ or less; $\mathrm{PM}_{10}$, particulate matter with a diameter of $10 \mu \mathrm{m}$ or less; $\mathrm{SO}_{2}$, sulfur dioxide

Figure 2

Multivariable logistic regression model. Estimated associations of the increase by interquartile range of yearly air pollution and chronic kidney disease.

\begin{tabular}{lcccc} 
& \multicolumn{3}{c}{ Statistics for each study } & \\
\cline { 2 - 4 } & $\begin{array}{c}\text { Odds } \\
\text { ratio }\end{array}$ & $\begin{array}{c}\text { Lower } \\
\text { limit }\end{array}$ & $\begin{array}{c}\text { Upper } \\
\text { limit }\end{array}$ & p-Value \\
$\mathrm{NO}_{2}$ & 1.01 & 0.99 & 1.04 & 0.30 \\
$\mathrm{SO}_{2}$ & 0.99 & 0.97 & 1.03 & 0.90 \\
$\mathrm{PM}_{10}$ & 1.01 & 0.99 & 1.02 & 0.3 \\
$\mathrm{PM}_{2.5}$ & 0.98 & 0.97 & 0.99 & 0.03
\end{tabular}

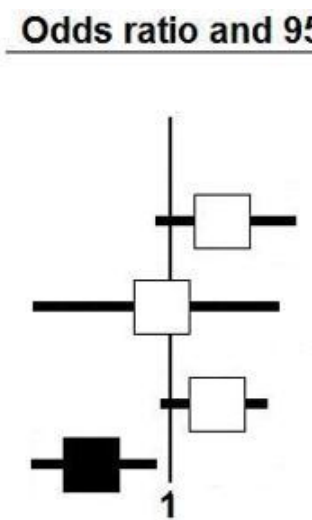

Model was model was adjusted for seasonality and long-time trends, weather conditions: temperature, humidity, atmospheric pressure, age, gender, and clinical variables including obesity, atrial fibrillation, hyperlipidemia, diabetes mellitus, arterial hypertension.

Abbreviations: $\mathrm{NO}_{2}$, nitrogen dioxide; $\mathrm{PM}_{2.5}$, particulate matter with a diameter of $2.5 \mu \mathrm{m}$ or less; $\mathrm{PM}_{10}$, particulate matter with a diameter of $10 \mu \mathrm{m}$ or less; $\mathrm{SO}_{2}$, sulfur dioxide

Figure 3 
Log linear regression model. Estimated associations of the increase by interquartile range of weekly air pollution and estimated glomerular filtration rate. 